Here let me protest against the common method of estimating intellectual work by numerical standards alone. I have heard it said that some men are possessed by a statistical devil. They can only think in figures: they will ask, in respect to a new acquaintance, how much is he worth ; of a library, how many volumes; of an orchestra, how many pieces; of a college, how many students. I have known the expenses of an institution made a dividend, and the number of scholars the divisor, the quotient representing the cost of each pupil. All this is wrong, absolutely and wholly wrong. If such a standard were allowable, the largest number of scholars taught by the cheapest teacher would be the greatest success. It is not the number but the quality of students which determines the character of a high school. It is important to count; it is better to weigh.

Having spoken of what the university does for individuals, I add that it has a second function. It benefits associated as well as inciividual man. It renders services to the community which no demon of statistics can ever estimate, no mathematical process ever develop. These functions may be stated as the acquisition, conservation, refinement, and distribution of knowledge.

These carefully chosen words I proceed to explain.

I. It is the business of a university to advance knowledge every professor must be a student. No history is so remote that it may be neglected; no law of mathematics is so hidden that it may not be sought out; no problem in respect to physics is so difficult that it must be shunned. No love of ease, no dread of labour, $\mathrm{n} n$ fear of consequences, no desire for wealth, will divert a band of well chosen professors from uniting their forces in the prosecution of study. Rather let me say that there are heroes and martyrs, prophets and apostles of learning as there are of religion. To the claims of duty, to the responsibilities of station, to the voices of enlightened conscience, such men respond, and they throw their hearts into their work with as much devotion, and as little sclfishness, as it is possible for human nature to exhibit. By their labours knowledge has been accumulated, intellectual capital has been acquired. In these processes of investigation the leading universities of the world have always been engaged.

This is what laboratories, museums, and libraries signify. Nothing is foreign to their purpose, and those who work in them are animated by the firm belief that the advancement of knowledge in any direction contributes to the welfare of man. Nor is rescarch restricted to material things; the scholars of a university are equally interested in all that pertains to the nature of man, the growth of society, the study of language, and the establishment of the principles of intellectual and inoral conduct.

2. Universities are conservative. They encourage the study of the history, the philosophy, the poetry, the drama, the politics, the religion, in fine, the experience of antecedent ages. Successors of the ancient monasteries, they keep alive in our day the knowledge of ancient languages and art, enrich the literature of our mother tongue, hold up to us the highest standards of excellence in writing, and enable us to share in the thoughts of the noblest of our race. Let me especially remind you that to the universities men turn instinctively for light on the interpretation of the Scriptures. When new manuscripts are discovered, or new versions are proposed, or new monuments are unearthed, it is $t$, the universities, where the knowledge of ancient ind remote tongues has been cherished, that the religious world looks for enlightenment and guidance. Their dominant influence is highly spiritualising; I would even go farther and say that it is truily religious. I am not unmindful that within the academic circles men are found whose spiritual insight is but dim-so it is in all other circles-but I assert, without fear of contradiction, that the influence of study is, on the whole, favourable to the growth of spiritual life, to the development of uprightness, unselfishness, and faith, or, in other words, it is opposed to epicureanism and materialism. In belief, there are tides as there are in the ocean, ebb and flow, ebb and flow; but the great ocean is there, with its deep mysteries, unchanging amid all superficial changes. Faith, with all its fluctuations, is as permanently operative in human thought as Knowledge.

3. Universities are refining. They are constantly, by laborious processes, by intricate systems of co-operation, and by ingenious methods, engaged in eliminating human errors and in submitting all inherited possessions to those processes which remove the dross and perpetuate the gold. No truth which has once been discovered is allowed to perish,-but the incrustations which cover it are removed. It is the universities which edit, interpret, translate, and reiterate the acquisitions of former generations both of literature and science. Their revelation of error is sometimes welcomed, but it is generally opposed; nevertheless the process goes on, indifferent alike to plaudits or reproaches. If their lessons are hard to the beginners, they lead the persevering to high enjoyment.

4. Universities distribute knowledge. The scholar does but half his duty who simply acquires knowledge. He must share his possessions with others. This is done in the first place by the instruction of pupils. Experience has certainly demonstrated that, with rare exceptions, those men are most learned who produce most. The process of acquiring seems to be promoted by that of imparting. The investigator who is surrounded by a bright circle of friendly inquisitors and critics finds his best powers developed by this influence. Next to its visible circle of pupils, the university should impart its acquisitions to the world of scholars. Learned publications are therefore to be encouraged. But beyond these formal and well recognised means of communicating knowledge, universities have innumerable less obvious, but not less useful, opportunities of conveying their benefits to the outside world.

These general principles $I$ propose to illustrate by asking you to go with me around the circle of the sciences, that we may observe the part which universities have taken, or should take, in respect to the various departments of knowledge.

Let me begin by saying that a university should discover and teach all that can be known of the Human Body. If you ask me why this is so important, I reply, in order that every one may be able to lead a healthier, stronger, and more rational life than is now possible for the want of more knowledge. Hospitals are essential to alleviate sufferings which have been encountered physical training is of great value; but still more important to humanity is the laboratory in which are studied the laws of life. A celebrated physiologist declares that "a hundred years of life is what Providence intended for man," and others tell us that most of our minor ailments may easily be avoided, ánd the number of efficient days may be largely increased. Science has proved that many diseases which used to scourge the civilised world may be prevented, and it has recently brought us within sight of new discoveries which will still further interrupt the progress of pestilence. The discoveries of anæsthetics have narvellously alleviated the sufferings of humanity. The causes and remedies of cerebral excitement and degeneration have never been understood as now, and the possibilities have never been so great for the restoration to their normal activity of the powers which have been alienated. In view of these great results and of these anticipations, it is clearly the duty of a university to study all the forms and functions of life which are manifested in organisms lower than man, all the laws which govern animal and vegetable growth, all that can possibly throw light on human physiology.

Those who are devoted to research of this kind, revealing with their microscopes the structure and the life-histories of the minutest organisms, are constantly, and in most unexpected ways, coming upon new illustrations of the plan of creation, which have an important bearing upon the welfare of man. 'They are the interpreters of nature and the benefactors of humanity ; and I do not hesitate to add that if there is any branch of learning which at the present time deserves the most gencrous support, it is surely l3iology, because of its obvious relations to the health and happiness of every human being. I cannot but think that those who oppose its study will be ranked in future years among the obscurantists of the nineteenth century.

( $T$ o be continued.)

\section{PRJEVALSKY'S EXPLORATIONS IN CENTRAL ASIA}

THE last number of the Izvestia of the Russian Geographical Society (xxi. 3) contains a letter from M. Prjevalsky, dated Lob-nor, January 29, r885. After having spent a month at Tsaidam, the expedition undertook, in August, its journey towards the west. A special disease, called khasa by the Mongols, and consisting in a strong fluxion of all four feet, attacked fifty three camels of the caravan, as well as all the cattle of the Mongols, and compelled the expedition to stop for a fortnight. Only seven camels succumbed to the disease, and on September 18 the expedition resumed its further advance, following the foot-hills of the Kuen-Jun-that is, of the border- 
range of the plateau of Thibet. Southern Tsaidam is an immense flat land, formerly the bottom of a lake, covered with brushwood at the foot of the mountains, and with salt clay elsewhere. A narrow salt lake, Dobasun-nor, extending west to east, receives the rivers Bayan-gol, Naidmin-gol, and Umu-muren. Pheasants are numerous in the brush and the small marshes covered with rush. Other birds, even migratory, are very few, as also the mammals, which must avoid a ground impregnated with salt. Only bears coming from Thibet are numerous when the fruits of the khormyk-brush are ripe. During Chingiz Khan's time the legend says, the region was inhabited by agriculturists, "Mongasy," who left their traces in irrigation canals; but now all Tsaidam is peopled only with Mongols, thinning in the south, living on cattle-breeding. The Umu-muren is the western boundary of the plains impregnated with salt of the sonthern Tsaidam. Further north and north-west, as far as the Altyntagh Mountains, extends an immense dry desert, the soil of which consists of clay, sand, and gravel. Several of its parts man never visits, and only savage camels wander on its barren surface. M. Prjevalsky met with only two places having plenty of fresh water and grazing grounds : at Hansy and at Has, where a lake of the same name has a circumference of nearly thirty miles. Two Cossacks were sent from Has to discover a route towards Lob-nor, and after a fortnight's searching they succeeded in finding a place reached by $M$. Prjevalsky in 1877 .

Leaving at Has some provisions under the guard of seven Cossacks, the remainder of the party went west to explore the valley nearly 150 miles long between the Altyn-tagh, in the north, and the Kuen-lun, in the south; the valley slowly rises from 9000 feet at Has to 14,00 ) feet at the junction of both chains of mountains. An easy passage across the Altyn-tagh leads them to Cherchen, and must have been utilised formerly on the route from Khotan to China, while another route led, vid Lob-nor, to the Sa-cheu oasis.

The excursions of the party aroand Has took fifty-four days, during which a region absolutely unknown before was explored. It has a very poor flora and fauna ; of mammals only a hundred antelopes were shot, and a new species of Ouis has been discovered. M. P'rjevalsky gave it the name of Ovis dalailame.

Most valuable geographical discoveries were made with regard to the central part of the Kuen-lun. In the longitude of Hansy this immense border-range of the Thibetan plateau is snow-clad, and reaches, under the name of Jin-ri, the height of 20,000 feet. To the east of this mountain-mass runs a chain named Marco Polo, which is accompanied on the north by a series of ridges parallel to it, and described under the names of Garynga, Dzukha, Toroi, and several others, until the Burkhan-buddha range. To the north-west of the Jin-ri, another snow-clad range, named "Columbus" by M. Prjevalsky, followed by a third range, also snow-clad and formerly unknown, continues further, to join the Altyn-tagh. A range, which has been seen only at a distance, and called "Problematic," runs due west of Jin-ri, and probably reaches also the Altyn-tagh; a high range, I2,500 to 3 , 000 feet above the sea-level, including an elongated salt lake, which does not freeze in winter, occupies the space between the "Problematic" ridge and those situated towards the north.

The climate of the region is very severe. In December the temperature was seen to fall during the night below $40^{\circ}$ Cels. Day and night strong westerly winds were blowing, often taking the force of a gale which filled the atmosphere with sand and dust. Snow was ve:y scarce; so also must be the rains in the summer, as far as one may judge by the barrenness of the region; this part of the Thibetan mountains must escape the influence of the south-westerly mon much moistness to North-Eastern Thibet. Water, however, is not scarce; the snow-summits supply many small rivers which flow from the mountains. Remains of summer-stations are seen on these rivers and streamlets, people coming there in search of gold, which seems to be as usual in North-West as in NorthEastern Thibet.

Returning in January to the station of Has, M. Prjevalsky resumed his journey to Lob-nor, I70 miles distant, where he was well received by his former acquaintances. There he proposed to stay throughout February to study the migrations of birds.

As known from his telegrams dated June 20 and July 13 (received on August 31), the expedition reached Keria, but was prevented from penetrating thence into Thibet, and the indefatigable traveller proposed to march on Khotan, and thence to Aksu.

\section{UNIVERSITY AND EDUCATIONAL INTELLIGENCE}

Cambridge. - The Class List of the Mathematical Tripos Part III., just issued, for which only wranglers can enter, contains in the first class the names of Messrs. Barnard (Emmanuel),

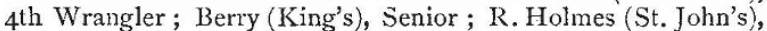
$5^{\text {th }}$; Love (St. John's), 2nd; Richmond (King's), 3rd ; and Roseveare (St. John's), bracketed 6th. Thus it includes the first five Wranglers, and one of the two bracketed sixth. The names are in alphabetical order.

The Sidgwick Prize has been awarded to Mr. T. Roberts, B. A., St. John's College.

The long list of lectures for this term, issued by the Special Board for Physics and Chemistry, includes, in addition to the ordinary courses of Prof. Liveing, Prof. Dewar, and Mr. Main, Mr. Pattison Muir's, on Principles of Chemistry; Dr. Kuhemann's, on Methods of Analysis and Principles of Organic Chemistry; and Mr. Heycock's, on Chemical Philosophy.

Demonstrations and practical courses suited to the various classes of students, will be given in the University, St. John's, Caius, and Sidney College Laboratories, and Prof. Liveing gives a course of Spectroscopic Chemistry; and Mr. Robinson, one on Chemistry as Applied to Agriculture.

-The courses of Physics include Prof. Thomson, on Magnetism; and lectures on various branches by Messrs. Atkinson, Glazebrook, Shaw, and Hart ; and practical courses at the Cavendish Laboratory. Elementary and Advanced Demonstrations in Mineralogy will be given.

Prof. Stuart is lecturing on Theory of Structures.

In Geology Prof. Hughes begins a course of lectures on a district to be visited at Easter on January 26, and also lectures on the Principles of Geology. Other work is divided among Messrs. Teall, T. Roberts, Marr, and Harker.

In Physiology the usual lectures are being given by Prof Foster, Drs. Lea, Gaskell, and Hill, and Mr. Langley. Prof. Macalister lectures on the Organs of Digestion and Reproduction Prof. Newton on the Geographical Distribution of Vertebrates. Mr. Hans Gadow's course is on the Morphology of the Sauropsida (recent and extinct); other courses are conducted by Messrs. Sedgwick, Harmer, and Weldon.

Dr. Vines's general elementary course of Botany is continued, supplemented by Mr. F. Darwin on the Biology of Plants (advanced); Mr. Gardiner on the Anatomy of Plants (advanced); Mr. Potter's demonstrations on Advanced Systematic Botany.

Advanced work in Mathematics is represented by Prof Stokes on Physical Optics, Prof. Adams on Lunar Theory, and Prof. Thoms on on Electro-magnetism. Mr. Glazebrook is lec turing on the Theory of Light, Mr. Hobson on Higher Dynamics, Mr. Macaulay on Thermodynamics, and Mr. Forsy th on Higher Algebra. Dr. Besant lectures on Analysis, Mr. H. M. Taylor on Higher Plane Curves, Mr. Stearn on Electrostatics, Mr. Larmor on Theory of Conduction and Analytical Optics.

THE number of students inscribed in the several Universities of the Italian kingdom amounts to $15,15 \mathrm{I}$; excepting 200 who follow the free Universities, all of them follow the Government teachers, viz. law students, 5133 ; medical, 6132 ; science, 1627 ; literature and philosophy, 44.I. The largest number of students in proportion to the population is recorded in Central Italy, the largest number of law students in the Neapolitan States, the largest number of science students in Northern Italy, the largest proportional number of philosophical and literary students in Central Italy.

\section{SCIENTIFIC SERIALS}

The Quarterly Fournal of Microscopical Science, No. ci., November 1885 , contains:- On the relations of the yolk to the gastrula in Teleosteans and in other Vertebrate types, by J. $T$. Cunningham (plates $\mathrm{I}-4$ ).- - On the structure and function of the sphæridia of the Echinoidea, by Howard Ayers (plate 5). Suggests that these organs have for their function the perception of chemical changes in the surrounding water (i.e. taste 